\title{
Gloomy outlook ahead
}

A though many laser systems manufacturers have announced positive financial results for the end of 2008, they warn of bad news to come. The current economic crisis has hit many firms hard and, as is common in such situations, acquisitions and staff redundancies abound.

Positive results include IPG Photonics' revenues, up by $21 \%$ for 2008 ; Micronic's sales, up by $8 \%$ for 2008 ; and Ultratech fourthquarter sales, up by $15 \%$. But for some the figures are not so promising. Rofin Sinar has reported a $21 \%$ reduction in net sales and a 55\% reduction in net income for the first quarter of fiscal 2009 compared with the same period in 2008. The company saw a decrease in sales of its products for macro applications (welding, cutting and surface treatment) of $32 \%$ and a decrease in micro (fine processing of small targets) sales of $14 \%$ for the first quarter of fiscal 2009. Günther Braun, CEO of Rofin Sinar, says, "With very few exceptions, we experienced diminished demand across all industries, even in the photovoltaic industry, which is something we have never seen before."

Laser materials processing systems are used in a huge variety of industries, each with their own dynamics, so identifying market

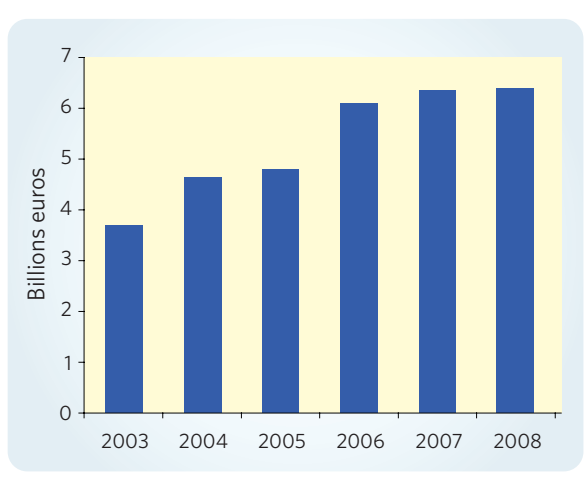

The world market for laser systems [in billions of euros] has flattened in recent years and may well decline in 2009.

trends is difficult. However, it seems that both macro and micro materials processing have been affected.

"While many companies are reporting growth in 2008 compared with 2007, order logging started to decrease by mid-2008," says Arnold Mayer, whose company, Optech Consulting in Switzerland, specializes in tracking the laser materials processing market.

"Production volumes started to decrease in the third and fourth quarter of 2008 and we will only see the full effects of the crisis in the financial results for 2009."

Many companies, mainly in the microprocessing markets, are already making redundancies. For example, laser microengineering systems supplier ESI has cut its workforce by $12 \%$; Swedish photomask manufacturing equipment vendor Micronic has cut 96 staff despite growth in 2008; and lithography tool supplier Cymer has announced 100 job cuts just a few months after making 85 people redundant (see news story below).

Mayer points out that the laser microprocessing market so far has weathered the downturn better than the semiconductor equipment market, as it also includes equipment for manufacturing solar cells and flat-panel displays. And although the crisis is also severely affecting macroprocessing markets, Mayer says it could be worse. "The laser macroprocessing market is still developing better than the machine tool market," says Mayer. "This downturn has taken hold vigorously, and companies have felt an effect within two quarters. Nobody knows how long or deep this downturn will be."

\section{Cymer reports job losses}

Cymer has announced a net income of US $\$ 36.5$ million for 2008 compared with a net income of US $\$ 88.4$ million for 2007 . The fourth-quarter performance was particularly poor with net income of US\$4 million compared with US\$21 million in the same quarter of the previous year.

Bob Atkins, Cymer's chief executive officer, says, "Cymer employees executed well in a very difficult business environment. We extended our argon fluoride (ArF) immersion market leadership and made continued progress towards the development and commercialization of our extreme ultraviolet (EUV) light source technology."

For the full year 2008, the company shipped a total of 100 light sources, for advanced chip-making applications.

Commenting on the outlook, Atkins states, "The current business environment is quite uncertain, characterized by shrinking lithography-tool demand, and decreasing chip-maker factory utilization in the second half of 2008. Looking at the first quarter of 2009, demand for new light sources and installed base products has declined further since our mid-January preliminary revenue estimate."
In the meantime, the company has taken some cost-cutting measures. These include a $10 \%$ reduction in personnel or an approximate 100 headcount reduction; temporary $10 \%$ reduction in employee base pay; and considerable reduction in nonessential operating and capital expenditures.

Based on the limited information that exists, the company currently anticipates that its first-quarter 2009 revenue could decrease by 30 to $35 \%$ compared with revenue for the fourth quarter of 2008 .

\section{IPG responds to downturn}

IPG Photonics, the fibre laser specialist, has reported that revenues for the full year 2008 increased by $21 \%$ to US $\$ 229.1$ million from US $\$ 188.7$ million in 2007, and net income increased by $23 \%$ to US $\$ 36.7$ million from US\$29.9 million last year. For the fourth quarter of 2008 , revenues increased by $6 \%$ to US $\$ 58.2$ million and net income increased by $9 \%$ to US $\$ 9.1$ million compared with the fourth quarter of 2007.

The company saw particular strength in Germany, where it increased fourth-quarter sales by $48 \%$ year over year, and Japan, where it saw $25 \%$ sales growth. Despite the strength in Japan, overall sales to Asia were down $10 \%$ as a result of weakness from marking applications in China. Overall sales in Europe and the Rest of the World were up, with North America relatively flat for the quarter.

Despite the positive revenue figures, IPG certainly has not been immune to current turmoil in the world economy. Over the past six months (October 2008 to March 2009), IPG's stock has halved in value from US\$16 to US\$8.

To cope with the current global financial crisis, the company has put in place several cost-cutting procedures. "First, we are decreasing our costs of goods by lowering component costs through technological improvements and implementation of in-house production of several critical parts that have been previously outsourced. In addition, we are cutting expenses by freezing new hiring, cutting overtime, curtailing bonuses, lowering headcount through attrition and implementing tighter spending controls," says Valetin Gapontsev, IPG's chief executive officer. "With these initiatives, we estimate that we can generate $\$ 4.0$ to $\$ 6.0$ million in annual operating expense savings."

For the first quarter of 2009, IPG Photonics expects revenues in the range of US $\$ 45$ million to US $\$ 50$ million. 